\title{
Field Performance Evaluation of a Small-Scale Drip Irrigation System Installed in the Upper West Region of Ghana
}

\author{
Hamidatu S. Darimani' ${ }^{1}$, Neolli Kpoda ${ }^{2}$, Sumaila M. Suleman ${ }^{1}$, Alhassan Luut ${ }^{1}$ \\ ${ }^{1}$ Department of Agricultural Engineering, Dr. Hilla Limann Technical University, Wa-Upper West Region, Ghana \\ ${ }^{2}$ Department of Animal Biology and Physiology, Joseph Ki-Zerbo University, Ouagadougou, Burkina Faso \\ Email: hamidnid2012@gmail.com
}

How to cite this paper: Darimani, H.S., Kpoda, N., Suleman, S.M. and Luut, A. (2021) Field Performance Evaluation of a Small-Scale Drip Irrigation System Installed in the Upper West Region of Ghana. Computational Water, Energy, and Environmental Engineering, 10, 82-94.

https://doi.org/10.4236/cweee.2021.102006

Received: March 19, 2021

Accepted: April 25, 2021

Published: April 28, 2021

Copyright $\odot 2021$ by author(s) and Scientific Research Publishing Inc. This work is licensed under the Creative Commons Attribution International License (CC BY 4.0).

http://creativecommons.org/licenses/by/4.0/

\begin{abstract}
This study was conducted to evaluate the water application uniformity for a drip irrigation system, considering the water quality and the duration of usage. The uniformity parameters, Emission Uniformity (EU \%) and Uniformity Coefficient (UC \%) were determined for the drip irrigation system installed over a year of performance. The procedures are based on taking measurements of emitter discharge along selected driplines on a sub-main. The catch can be identified as L1A, L1B, L1C, L1D, same for L2A to L2D, L3A to L3D and L4A to L4D. This gave a total of sixteen (16) measurement positions as there were 4 driplines. Results indicated that the uniformity of water application was $90 \%$ indicating that the emitter was still good after a year of installation. The average discharge rate was $0.57 \mathrm{l} / \mathrm{h}$. The uniformity coefficient (UC \%) for the gravity-fed drip irrigation system was $78 \%$, indicating good water application and was quite significant for the evaluation of the uniform distribution of water for the design. The expansion of this irrigation method in rural communities could contribute to relevant water savings in most areas of the Upper West Region of Ghana.
\end{abstract}

\section{Keywords}

Drip Irrigation, Field Performance, Water Application, Uniformity

Coefficient, Clogging

\section{Introduction}

In Ghana, as in other parts of the world, the amount and timing of rainfall are not adequate to meet the moisture requirement of crops and so irrigation is necessary to meet the needs of food and fibre designed to allow farming in arid and 
semi-arid regions to reduce drought. The Ministry of Food and Agriculture (MoFA) of Ghana promotes small-scale irrigation (SSI) as a climate variability adaptation measure, given the decline in total rainfall and increasing intermittent dry spells during the rainy season cropping period [1]. Efficient use of available irrigation water is essential for increasing agricultural productivity for the increasing Ghanaian population. The proper design of a gravity-fed drip irrigation system can result in cost benefits and zero environmental pollution as compared to the conventional water pump. The integration of gravity force in the irrigation and agriculture sector is found to be a sustainable and economically feasible alternative [2].

The climatic environment in the Upper West Region is seasonal in terms of rainfall and diurnal in temperature. The dry season period from November to March produces deficit soil available water (DAW) of up to $61 \%$ in January to $76 \%$ of total available water (TAW) in March [3]. Hence produces a water deficit that does not support sustained crop growth, hence causing the death of nutritive natural crop supply. This impaired environmental condition can be repaired by the artificial supply of water to meet the optimal water demand of the soil for sustained crop productivity in a season of soil water scarcity. This requires irrigation for optimum production. The use of drip irrigation is known to provide a root contact supply that reduces evaporative loss of applied irrigation water, since it is a sub-surface applied in close contact to roots [4].

Drip or Trickle irrigation systems are specifically designed to apply the known amount of water frequently, steadily, slowly and directly to the root zone of plants on the field. It is an efficient form of irrigation that can have water application and crop water use efficiency as high as $90 \%-95 \%$ when properly designed, installed and managed [5]. Drip irrigation system is becoming popular in Sub-Saharan Africa due to its ease of adoption and construction from local materials [6]. There is an urgent need to increase water productivity and water application efficiency due to the continuous increase in population, increase in demand for vegetables and increased pressure on land available for agriculture coupled with the overwhelming effect of climate change [7]. There is the need to appropriately dispense and manage water as a scarce resource through the use of a well-managed water-saving irrigation system. Several studies have been conducted to calculate the performance of drip irrigation and to define the best indicators for its assessment. Many hydraulic indicators were proposed, particularly distribution uniformity (DU), pressure uniformity (PU) and irrigation efficiency [8]. Several authors have developed and applied these indicators to find a more precise way of calculating them and, hence, improving water productivity [9].

A considerable number of studies have reported on the theoretical performance of drip irrigation, which is often measured in hydraulic laboratories. These indicators mainly account for variations in pressure and discharge due to the quality of the drippers and to the hydrodynamic characteristics of the flows along driplines. However, few studies have specifically evaluated the perfor- 
mance of drip irrigation in use, resulting in underestimations or even completely disregarding the actual performance of drip irrigation and missing the opportunity of remedying existing problems in irrigation schemes with pressurized systems [10] [11].

Performance assessment of drip irrigation in use is complex and time-consuming as it changes over time due to wear and the associated deterioration of the equipment, especially in the absence of maintenance or renewal. Similarly, farmers' practices and choices greatly affect actual irrigation performance. In other words, drip irrigation technology cannot achieve the expected miracle by itself [12]. Vidal et al. (2001) [13] reported that excellent as well as poor results were obtained in five Mediterranean countries, depending on the maintenance and renewal of irrigation equipment and on actual irrigation practices. While the performance of a drip irrigation network, as designed by engineers, is a reference value for the installation of the network, the actual irrigation performance can diverge considerably from theoretical values: "Drip irrigation systems can achieve high degree of uniformity in water application; however, the efficient water use depends also on how the irrigation scheduling is conducted" [14]. Conclusions concerning water savings and increased water productivity must therefore be based on the assessment of actual irrigation performance rather than on theoretical values.

Few authors have examined the actual performance of drip irrigation, mainly in individual drip projects [10] [15]. However, very little data are available on the performance of drip irrigation projects at the field level in large-scale or small irrigation schemes [11]. Specifically, very few data exist on the performance of drip irrigation system in Ghana particularly in the Upper West Region where the study was conducted. A drip irrigation system was installed over a year on the field. A Field evaluation was done to determine uniformity co-efficient of the system. The objective of this study was to evaluate the performance of a gravity-fed surface drip system installed in the field over a year. The specific objectives were to assess the gravity-fed drip irrigation emitter discharge rate along the dripline and to assess gravity-fed drip irrigation emission uniformity (EU \%) and uniformity coefficient (UC \%).

\section{Methodology}

\subsection{Site Selection}

The study was carried out in residential backyard garden located at Kpaguri, Wa. Site analysis provided information essential for the proposed root zone irrigation design. Site factors considered in site selection were the soil type, the overall field area and topography (or changes in elevation), possible water sources (tank) and proximity to water sources, as well as quantities available for both seasonal and peak daily requirement.

\subsection{Gravity-Fed Drip Irrigation Set up and Installation}

The gravity-fed drip irrigation system for the trail was constructed from availa- 
ble materials. The materials that were used for the irrigation system of the small farm gravity drip irrigation system were: plastic water tank, mainline pipes, submainline pipe, lateral pipes, water filter and valves/regulators. The emitters were attached to laterals from the manufacturer. The system was a complete irrigation unit, all the pipes were made of PVC and it operated by gravity from a plastic tank of 1000 litres placed at $1.3 \mathrm{~m}$ above the ground level so that the system will have enough head for water pressure. The lateral lines which were connected to the sub mainlines were laid along the crop rows and micro emitters installed at spacing of $30 \mathrm{~cm}$. There is a drain tap at the bottom of the water tank for frequent flush out and cleaning from suspended solid particles. It did not use any external power for normal operation.

\subsection{Water Quality Determination}

Samples of water applied through the drip irrigation systems were taken during the field test to determine those important parameters that affect emitter clogging as in (Essien and Essien, 2014). Parameters tested for were Electrical Conductivity (EC), pH, Total Suspended Solids (TSS), Total Dissolved Solids (TDS), Total Iron ( $\mathrm{Fe}$ ), Calcium ( $\mathrm{Ca}$ ), Magnesium ( $\mathrm{Mg}$ ), Manganese (Mn), Bicarbonates $(\mathrm{Bc})$, and Bacterial Count (BC). Water analyses were carried out in the laboratory using standard procedures (Wu et al., 2010). The soil physicochemical properties in the study area were also determined using standard laboratory methods conducted at the Ghana Water Company Limited Laboratory, Wa.

\subsection{Sample Collection and Characterization}

Soil physical properties and analysis were carried in the laboratory. Water was sampled from the borehole as source of water for the study were analysed at Ghana Water Company Laboratory, Wa. Soil samples were collected at various soil depths and were placed in different moisture content cans labelled 1 and 2, 3, and 4. Soil samples were tested for Moisture Content, Soil texture, Dry Bulk Density, Total Available Moisture Capacity, Evapotranspiration Rate.

\subsection{Evaluation Procedure}

The evaluation was carried out according to Raphael et al. (2018) [6]; Zamaniyan et al. (2014) [16]. These procedures are based on taking measurements of emitter discharge along selected driplines on a sub-main. Four positions were tested on each dripline which is $12 \mathrm{~m}$ long each: one located on the first emitter point close to the inlet, one at the far end, and two in the middle at the one-third and two-thirds positions. Each dripline is identified as L1, L2, L3, ..., L18. Emitter position on each dripline identified as $\mathrm{A}, \mathrm{B}, \mathrm{C}$, and $\mathrm{D}$ starting from the emitter point near the submain line spaced at equal distances of $4.5 \mathrm{~m}$ on the dripline. Thus, the catch can was identified as L1A, L1B, L1C, L1D, same for L2A to L2D, $\mathrm{L} 3 \mathrm{~A}$ to $\mathrm{L} 3 \mathrm{D}$ and $\mathrm{L} 4 \mathrm{~A}$ to $\mathrm{L} 4 \mathrm{D}$. This gives a total of 16 measurement positions as there were 4 driplines. 
The depth was estimated in the field by digging into the soil and then measuring the depth using a field tape from the top of the soil to the dry layer zone of the soil. Three different measurements were made and their average values gave the wetting depth of gravity-fed drip irrigation system. The effective wetting diameter was estimated in the field by measuring the diameter of their moisture spread. Three different measurements were made and their average values gave the wetting diameter of gravity-fed drip irrigation system.

\subsubsection{Emitters Discharge Rates}

The average discharge rates of the sampled emitters according to the valves and distances from the water source were measured with an improvised method. This was done by applying the volumetric method in which a disposable plastic cup was attached to four emitters and discharged water collected into a measuring cup for an hour during a three-day experiment. The following parameters were used to evaluate the gravity fed drip system based on the measured data in the study and were as follows: Average Emitter Discharge Rate $\left(q_{a}\right)$. The mean amount of water released by each dripper per unit time is the average emitter discharge rate $\left(q_{a}\right)$. It is obtained by using the equation of Zamaniyan et al., 2014 [16];

$$
q_{a}=\frac{1}{n} \sum_{i=1}^{n} q_{i}
$$

where: $q_{i}=$ flow rate of the emitter $i \mathrm{~m}^{3} / \mathrm{s}$ or $(1 / \mathrm{h})$;

$n=$ total number of emitters.

\subsubsection{Emitters Discharge Uniformity}

Emission uniformity (EU) is determined as a function of the relation between the average flow emitted by $25 \%$ of the emitters with the lowest flow and the mean flow emitted by all emitters, as shown in Equation [16] below:

$$
\mathrm{EU}=100 \frac{q_{25 \% \min }}{q}
$$

where: $\mathrm{EU}=$ Emission Uniformity (\%);

$q_{a}=$ average of $25 \%$ of the lowest values of flow rate $(1 / \mathrm{h})$;

$q=$ average discharge rate of all sampled emitters $(1 / \mathrm{h})$.

The evaluated system is classified according to the EU values, following Merriam and Keller (1978) [17]; Kumari et al. (2018) [18]; Capra and Scicolone (1998) [19] as shown in Table 1.

\subsubsection{Uniformity Coefficient (UC)}

The water application uniformity of drip irrigation system was evaluated using the uniformity coefficient formula reported by Asif et al. (2015) [20] and Jatoth et al. (2017) [21] is stated and shown in Table 2 below:

$$
\mathrm{UC}=100\left[1-\frac{1}{n q_{a}} \sum_{i-1}^{n}\left|q_{i}-q_{a}\right|\right]
$$

where: $n=$ number of emitters under consideration; 
Table 1. System classification according to Emission Uniformity (EU) values.

\begin{tabular}{ccc}
\hline EU (\%) & $\begin{array}{c}\text { Merriam and Keller (1978) [17]; } \\
\text { Kumari } \text { et al. (2018) [18] }\end{array}$ & Capra and Scicolone (1998) [19] \\
\hline$<66$ & Poor & Mean \\
$66-70$ & Poor & \\
$70-79$ & Acceptable & High \\
$80-84$ & Good & \\
$84-90$ & Good & \\
$90>$ & Excellent & \\
\hline
\end{tabular}

Table 2. Classification of uniformity coefficient.

\begin{tabular}{cc}
\hline Uniformity coefficient, UC (\%) & Classification \\
\hline Above 90 & Excellent \\
$80-90$ & Good \\
$70-80$ & Fair \\
$60-70$ & Poor \\
Below 60 & Unacceptable \\
\hline
\end{tabular}

$q_{a}=$ mean flowrate of the emitter $i(1 / \mathrm{h})$;

$q_{i}=$ flowrate of the emitter $i(\mathrm{l} / \mathrm{h})$.

\subsection{Data Analysis Techniques}

The recorded flow rate of each sampled point in the system was arranged in ascending order (ranked) using an excel spreadsheet. From the result obtained, the outliers, the very smallest and highest flowrates not consistent with the rest of the recorded flowrates were left out. Data obtained from field was analysed using excel and IBM SPSS version 20.

\section{Results and Discussion}

\subsection{Physio-Chemical Soil Properties}

The results of the physiochemical properties analysis of the soil sampled from the study area as presented in Table 3 . The soil of the study field was found to be loamy sand with an apparent specific gravity (bulk density) were $1.43 \mathrm{~g} / \mathrm{cm}^{3}$ at $10 \mathrm{~cm}$ depth of sampling, $1.39 \mathrm{~g} / \mathrm{cm}^{3}$ at $20 \mathrm{~cm}$ depth and $1.41 \mathrm{~g} / \mathrm{cm}^{3}$ at $30 \mathrm{~cm}$ depth. In this research, the core method was used in determining the dry bulk density of the collected soil samples. Several research findings have shown that, average soil bulk density for a cultivated loamy sand range between $1.1 \mathrm{~g} / \mathrm{cm}^{3}$ to $1.4 \mathrm{~g} / \mathrm{cm}^{3}$ [22]. Soil porosity being the voids between soil particles and peds which allows for water movement and retention along plants and organisms activities takes place. They store water or circulate air to roots, and larger pores drain excess water. The test conducted on porosity found that, the soil porosity 
Table 3. Soil physiochemical properties.

\begin{tabular}{|c|c|c|c|c|}
\hline & Parameter & $0-10 \mathrm{~cm}$ & $10-20 \mathrm{~cm}$ & $20-30 \mathrm{~cm}$ \\
\hline \multirow{7}{*}{ Physical Properties } & $\%$ SAND & 84.00 & 90.00 & 86.00 \\
\hline & $\%$ SILT & 12.00 & 6.00 & 10.00 \\
\hline & $\%$ CLAY & 4.00 & 4.00 & 4.00 \\
\hline & TEXTURE & LOAMY SAND & SAND & LOAMY SAND \\
\hline & B.D $\left(\mathrm{g} / \mathrm{cm}^{3}\right)$ & 1.43 & 1.39 & 1.41 \\
\hline & \% POROSITY & 45.14 & 46.60 & 45.64 \\
\hline & $\%$ O.M & 11.96 & 3.97 & 4.69 \\
\hline \multirow{8}{*}{ Chemical Properties } & $\mathrm{pH} \mathrm{1:2.5}$ & 6.95 & 7.58 & 7.74 \\
\hline & $\%$ O.C & 6.94 & 2.30 & 2.72 \\
\hline & $\%$ T.N & 0.67 & 0.22 & 0.26 \\
\hline & Ca me/100g & 15.34 & 10.65 & 3.20 \\
\hline & $\mathrm{Mg}$ me/100g & 2.77 & 1.70 & 0.43 \\
\hline & $\mathrm{K}$ me/100g & 0.28 & 0.02 & 0.01 \\
\hline & $\mathrm{Na}$ me/100g & 0.35 & 0.01 & 0.19 \\
\hline & ppm P & 358.78 & 287.81 & 187.27 \\
\hline
\end{tabular}

was $45.14 \%, 46.60 \%$ and $45.64 \%$ at $10 \mathrm{~cm}, 20 \mathrm{~cm}$ and $30 \mathrm{~cm}$ depth respectively. With this percent of porosity, the soil had the ability to allow for better water movement through the soil along with better aeration for better plant root development. Essien \& Essien (2014) [4] argued that porosity is the total amount of pore space in the soil and the recommended porosity of soil for crop cultivation ranges from $30 \%$ and $60 \%$. Porosity also affects the rate of movement of air and water. The soil from the study area is good for crop cultivation with an average of $45.79 \%$ porosity.

The field capacity was $15.26 \%$ at $10 \mathrm{~cm}$ depth, $15.35 \%$ at $30 \mathrm{~cm}$ depth and $15.37 \%$ at $40 \mathrm{~cm}$ of root zone depth in the experimental field. The permanent wilting point (PWP) was obtained as $6.97 \%$. Thus, root zone depth moisture distribution shows that, at lower depths, the available water was $22.50 \mathrm{~cm} / \mathrm{hr}$ for the soil type at site. The water holding capacity of the site soil was computed with $\mathrm{FC}=15.33 \%, \mathrm{PWP}=6.97 \%$, therefore available moisture content (AMC) for soil was $8.36 \%$. The textural classification of the soil contained sand, silt and clay the ratio of $84.00 \%, 12.00 \%$ and $4.00 \%$ respectively at $0-10 \mathrm{~cm}$ depth given it a loamy sand, $90.00 \%$ sand, $6.00 \%$ silt and $4.00 \%$ clay at $20 \mathrm{~cm}$ depth given sand whilst at $30 \mathrm{~cm}$ depth gave $86.00 \%$ sand, $10.00 \%$ silt and $4.00 \%$ clay also found to be loamy sand. The average textural classification of the soil contained sand, silt and clay in a ratio of $86.67 \%, 9.33 \%$ and $4.00 \%$ respectively at $0-30 \mathrm{~cm}$ depth for loamy sand soil. According to USDA-NRCS (2018) [22], loamy sandy soils usually have good aeration, but cannot hold water well. So, both water and nutrients can easily leach through the soils. Clay soils retain more water and nu- 
trients than sand, but there is little infiltration of the water and less oxygen for the plant due to smaller pore space than those of coarser textures.

\subsection{Irrigation Water Quality}

The biological and chemical characteristics of the untreated borehole used for the drip irrigation in the study are shown in Table 4 and Table 5. All parameter were found to be below the level of concern. Turbidity as an indicator of water clogging potential was also found to be very low, the same with the level of Total Dissolved Solids. The source of water for the study met chemical standard parameters but shows faecal contamination and hence requires disinfection to make it safe for domestic use as well. The fact that $\mathrm{Fe}, \mathrm{Mn}$ and Bacterial count were not detectable is an indication that bacterial slimming which causes precipitation, sedimentation and clogging is not likely to occur. These results also indicate that borehole water was safe for usage in crop cultivation and contained less dissolved substances value of which is very good as demonstrated in Akhtar et al. (2014) [23]; FAO (2019) [24].

The $\mathrm{pH}$ is the concentration of hydrogen ions $(\mathrm{H}+)$ and hydroxyl ions $(\mathrm{OH}-)$ in the water. It is used to determine the acidic, basic or neutral behavior of water. The $\mathrm{pH}$ values for the irrigation water was found to be 6.40 indicates that the

Table 4. Microbiological analysis results.

\begin{tabular}{ccc}
\hline Determinants & Requirement & Test Results \\
\hline Total viable count $($ count $/ \mathrm{ml})$ & 500 & 61.00 \\
$E$-coli $($ count $/ 100 \mathrm{ml})$ & Not detected & 0.00 \\
Total Coliform $($ count $/ 100 \mathrm{ml})$ & Not detected & 14.00 \\
\hline
\end{tabular}

Table 5. Irrigation water physio-chemical analysis.

\begin{tabular}{cccc}
\hline Parameter & Units & Results & Standard Specification \\
\hline pH & & 6.4 & $6.5-8.5$ \\
Colour & Pt.CO & 5.0 & $0-15$ \\
Turbidity & FTU & 1.4 & 5.00 \\
Conductivity & us/cm & 227.0 & N/A \\
TDS & ppm & 104.0 & 1000 \\
TSS & ppm & 37.0 & N/A \\
Calcium $(\mathrm{Ca})$ & ppm & 14.00 & N/A \\
Magnesium $(\mathrm{Mg})$ & ppm & 4.9 & N/A \\
Bicarbonates & ppm & 31.0 & N/A \\
Alkalinity & ppm & 49.0 & N/A \\
Chloride $(\mathrm{Cl})$ & ppm & 32.00 & 250 \\
Iron (Fe) & ppm & 0.00 & 0.3 \\
Manganese & ppm & 0.002 & 0.4
\end{tabular}


water could be classified acidic water. The slightly acidic $\mathrm{pH}$ level of borehole water was not strong enough to prevent clogging especially after long accumulation of suspended solids and mineral precipitation even though it is suitable for agricultural uses [24]. The $\mathrm{pH}$ of water and soil could not harm the plant growth directly. $\mathrm{pH}$ highly affects the efficiency of coagulation and flocculation process [25].

\subsection{Irrigation System Performance}

The cumulative average discharge rates for the sampled laterals of the gravity-fed drip irrigation system of study are shown in Figure 1. The emitter average discharge rate along the laterals of the gravity-fed drip irrigation system range between $0.52 \mathrm{l} / \mathrm{hr}, 0.55 \mathrm{l} / \mathrm{hr}, 0.56 \mathrm{l} / \mathrm{hr}$ and $0.60 \mathrm{l} / \mathrm{hr}$ for L1 to L4 respectively for an hour duration. During a two-hour irrigation period, emitter's cumulative average discharge was $1.08 \mathrm{l} / \mathrm{hr}, 1.14 \mathrm{l} / \mathrm{hr}, 1.15 \mathrm{l} / \mathrm{hr}$ and $1.17 \mathrm{l} / \mathrm{hr}$ respectively. After three hours, average emitters discharge rates (cumulative) ranges between 1.68 1/hr and $1.78 \mathrm{l} / \mathrm{hr}$. However, the average discharge rate for the system under study was found to as $0.57 \mathrm{l} / \mathrm{hr}$. Previous studies by Raphael et al. (2018) [6] have also reported an average discharge rate of 0.5 to $0.6 \mathrm{l} / \mathrm{h}$.

Statistically, as shown in Table 6 the gravity generated from the $1.2 \mathrm{~m}$ overhead tank demonstrated to have significant effect on the discharge rate of the drip system. The elevated value of mean emitter discharge is closely related to the quality of irrigation water and occurs as a result of multiple factors, including physical, biological and chemical agents [16]. Other significant factors affecting emitter discharge include water temperature, quality with which the emitter is manufactured [26]. The variations observed from emitter average discharge rates could be as a result of the difference in land slope as similar reports made by Raphael et al. (2018) [6]. As indicated by James (1993) [26]; Raphael et al. (2018) [6] the emitter discharge variation mainly depends on pressure differences owing to difference in operation head, water temperature, quality with which the emitter is manufactured.

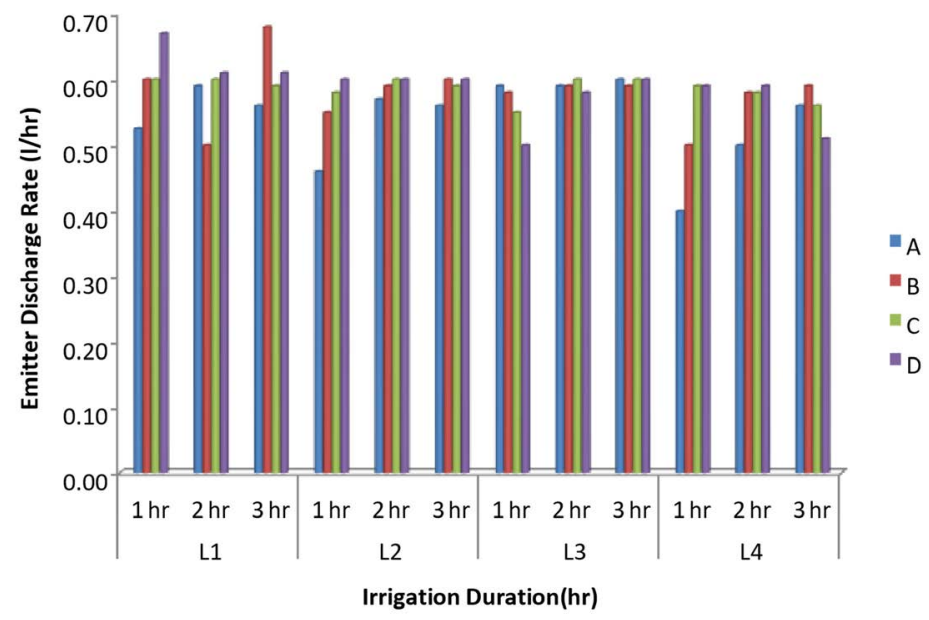

Figure 1. The discharge variation at various points on the laterals. 
Table 6. Multivariate tests.

\begin{tabular}{cccccc}
\hline & Effect & Value & F & Error df & p-Value \\
\hline \multirow{3}{*}{ Intercept } & Pillai's Trace & 1.000 & $58,215.803 \mathrm{~b}$ & 1.000 & 0.003 \\
& Wilks' Lambda & 1.000 & $58,215.803 \mathrm{~b}$ & 1.000 & 0.003 \\
& Hotelling's Trace & $174,647.408$ & $58,215.803 \mathrm{~b}$ & 1.000 & 0.003 \\
& Roy's Largest Root & $174,647.408$ & $58,215.803 \mathrm{~b}$ & 1.000 & 0.003 \\
\hline
\end{tabular}

\subsubsection{Emission Uniformity (EU)}

The absolute emission uniformity was found to be $90 \%$ for the gravity-fed drip irrigation system. Hence the drip irrigation system in water distribution uniformity is very good. The general ratings of EU values as indicated by Merriam and Keller (1978) [17]; Kumari et al. (2018) [18] illustrates that, a drip irrigation system with EU of $84 \%$ - $90 \%$ is very good. Slight variation in the uniformity of emitter flow rate however was present and may have been resulted from clogging and leakage in drip line with observation [27]. The clogging may be as a result of the lack of flushing (even though filter was incorporated). This problem of clogging could be handled (as also recommended by Storie, 1995 [28]) by periodic cleaning of filters, checking the pressure drop across the filter, checking the holes in the screens, and/or flushing the laterals at least two or three times a year. Flushing measures can be taken to prevent emitter clogging.

\subsubsection{Uniformity Coefficient}

Christiansen's coefficient of uniformity (CU\%) for the gravity-fed drip irrigation system was $78 \%$, indicating fair water application and was quite significant for the evaluation of the uniform distribution of water for the design. The water uniformity coefficient of the gravity-fed drip irrigation system under study from emitters was $78 \%$ and this value of the water uniformity coefficient was found not to be within the acceptable uniformity level of design (80\%) according to Al-Ghobari (2012) [29].

\subsubsection{Emitter Wetting Diameter}

The wetting depth ranged from $10.2 \mathrm{~cm}$ to $34.1 \mathrm{~cm}$ and the average wetting diameter was $23.59 \mathrm{~cm}$. Results obtained from the study showed that, after an hour, the drip recorded diameters of wetting zone of $10.2 \mathrm{~cm}$ and $11.8 \mathrm{~cm}$. Diameters observed after two hours of irrigation wetting zones were $26.6 \mathrm{~cm}$ to $29.7 \mathrm{~cm}$. Diameters ranging from $27.6 \mathrm{~cm}$ and $34.1 \mathrm{~cm}$ after three hours of irrigation. In order to investigate the effects of the gravity-fed on the related factor, data was subjected to MANOVA analysis, it had demonstrated that, the gravity generated from the $1.2 \mathrm{~m}$ high placed $1000 \mathrm{lt}$ water reservoir had significantly generated enough pressure for the drip system under study. This wetting circumference for 3 hours irrigation period was in line with the findings of in Isikwue et al. (2016) [30] that wetted diameter for a single dripper may be 30,60 , and $120 \mathrm{~cm}$ in light, medium and fine textured soils respectively. 


\subsubsection{Depth of Infiltration of Irrigated Water}

The average depth observed was $4.25 \mathrm{~cm}$ after an hour, $12.18 \mathrm{~cm}$ after two hours and $22.02 \mathrm{~cm}$ after three hours. The depth reached during an hour of irrigation ranges from $4.0 \mathrm{~cm}$ and $5.0 \mathrm{~cm}$. After two and three hours of irrigation, the depths recorded were between $11.4 \mathrm{~cm}$ to $12.3 \mathrm{~cm}$ and $21.7 \mathrm{~cm}$ to $22.5 \mathrm{~cm}$ respectively. Statistically, Table 6 shows significant effect of the gravity-fed drip irrigation system under study and depth of irrigated water for the period under consideration. In line with the finding of Isikwue et al. (2016) [30], the wetting depth of up to $1.5 \mathrm{~m}$ can accommodate $0.3-1.0 \mathrm{~m}$ effective rooting depth for small vegetables (such as spinach, carrot, lettuce, cabbage, garlic, onions etc.), 0.7 $1.5 \mathrm{~m}$ rooting depth for vegetables of solanium family and $0.6-1.5 \mathrm{~m}$ rooting depth for vegetables of cucumber family. The inference of good performance of the gravity-fed drip irrigation system is uniform water application, good pressure distribution, provision of enough moisture (water) for the plants within the crop root zone (adequate wetting depth) and good filtration. With the performance of the system, combine surface drip irrigation and nutrients management can be applied. This is in line with the findings of Roberto (2005) [31] and Ochedikwu (2015) [32] that high nutrient and water management have been achieved for several vegetable crops, including collard, mustard, spinach, and romaine under drip irrigation system. In addition, the system is well suited to meet all small-scale farmers' needs, both from an economic as well as an engineering standpoint, with many advantages as compared to traditional irrigation methods.

\section{Conclusion}

High irrigation water distribution uniformity is essential for the drip-irrigation system to reduce water losses in fields and maximize farmer's returns. In this study, the performance of the emitter with the low-pressure (gravity) drip-irrigation system was found significant for a $1.2 \mathrm{~m}$ overhead tank. The uniformity of water application was $90 \%$ indicating that the emitter was were still good after a year of installation. The average discharge rate was $0.57 \mathrm{l} / \mathrm{h}$. The uniformity coefficient (UC \%) for the gravity-fed drip irrigation system was $78 \%$, indicating good water application and was quite significant for the evaluation of the uniform distribution of water for the design. This irrigation method has many advantages and is easy to install. The expansion in rural communities could contribute to relevant water savings in most areas of the Upper West Region of Ghana.

\section{Conflicts of Interest}

The authors declare no conflicts of interest regarding the publication of this paper.

\section{References}

[1] MOFA (2014) Agric Sector Annual Progress Report. http://mofa.gov.gh/site/?page_id=14435?shared=email\&msg=fail 
[2] Setiawan, A., Purwanto, D.H., Pamuji, D.S. and Nurul Huda, N. (2014) Development of a Solar Water Pumping System in Karsts Rural Area Tepus, Gunungkidul through Student Community Services. Energy Procedia, 47, 7-14. https://doi.org/10.1016/j.egypro.2014.01.190

[3] Essien, O.E. and Essien, M.E. (2009) Basin-Scale Temporal Distribution of Water Resources Sensitivity of Components Contributions in Ikpa Catchment of Nigeria. Global Journal of Engineering and Technology, 2, 147-153.

[4] Essien, O.E. and Essien, M.E. (2014) Design and Evaluation of Gravity-Fed Perforated Tube Drip Irrigation for Dry Season Irrigation of Citrus Sinensis. International Journal of Engineering Inventions, 3, 28-35.

[5] Goyal, M.R. (2013) Management of Drip/Trickle or Micro Irrigation. CRC Press, Taylor \& Francis Crop Publication, Boca Raton, 408. https://doi.org/10.1201/b13110

[6] Raphael, O.D., Amodu, M.F., Okunade, D.A., Elemile, O.O. and Gbadamosi, A.A. (2018) Field Evaluation of Gravity-Fed Surface Drip Irrigation Systems in a Sloped Greenhouse. International Journal of Civil Engineering and Technology (IJCIET), 9, 536-548.

[7] Raphael, O.D., Ogedengbe, K., Fasinmirin, J.T., Okunade, D., Akande, I. and Gbadamosi, A. (2018) Growth-Stage-Specific Crop Coefficient and Consumptive Use of Capsicum chinense Using Hydraulic Weighing Lysimeter. Agricultural Water Management, 203, 179-185. https://doi.org/10.1016/j.agwat.2018.03.011

[8] Burt, C.M., Clemmens, A.J., Strelkoff, T.S., Solomon, K.H., Bliesner, R.D., Hardy, L.A. and Eisenhauer, D.E. (1997) Irrigation Performance Measures: Efficiency and Uniformity. Journal of Irrigation and Drainage Engineering, 123, 423-442. https://doi.org/10.1061/(ASCE)0733-9437(1997)123:6(423)

[9] Zhu, D.L., Wu, P.T., Merkley, G.P. and Jin, J. (2010) Drip Irrigation Lateral Design Procedure Based on Emission Uniformity and Field Microtopography. Irrigation and Drainage, 59, 535-546. https://doi.org/10.1002/ird.518

[10] van der Kooij, S., Zwarteveen, M., Boesveld, H. and Kuper, M. (2013) The Efficiency of Drip Irrigation Unpacked. Agricultural Water Management, 123, 103-110. https://doi.org/10.1016/j.agwat.2013.03.014

[11] Boularbah, S., Kuper, M., Hammani, A., Mailhol, J.C. and Taky, A. (2019) The Blind Angle: Performance Assessment of Drip Irrigation in Use in a Large-Scale Irrigation Scheme in Morroco. Irrigation and Drainage, 68, 925-936.

https://doi.org/10.1002/ird.2369

[12] Luquet, D., Vidal, A., Smith, M. and Dauzat, J. (2005) "More Crop per Drop": How to Make It Acceptable for Farmers? Agricultural Water Management, 73, 108-119. https://doi.org/10.1016/j.agwat.2005.01.011

[13] Vidal, A., Comeau, A., Plusquellec, H. and Gadelle, F. (2001) Case Studies on Water Conservation in the Mediterranean Region. IPTRID/FAO, Rome.

[14] Qiu, Y., Luo, J. and Meng, G. (2004) The Effect of Water Saving and Production Increment by Drip Irrigation Schedules. Wuhan University Journal of Natural Sciences, 9, 493-497. https://doi.org/10.1007/BF02830450

[15] Benouniche, M., Kuper, M., Hammani, A. and Boesveld, H. (2014) Making the User Visible: Analysing Irrigation Practices and Farmers' Logic to Explain Actual Drip Irrigation Performance. Irrigation Science, 32, 405-420.

https://doi.org/10.1007/s00271-014-0438-0

[16] Zamaniyan, M., Fatahi, R. and Boroomand-Nasab, S. (2014) Field Performance Evaluation of Micro Irrigation Systems in Iran. Soil and Water Research, 9, 135-142. https://doi.org/10.17221/8/2013-SWR 
[17] Merriam, J.L. and Keller, J. (1978) Farm Irrigation System Evaluation: A Guide for Management. Utah State University, Logan.

[18] Kumari, C.P., Bhagat, E.I.B. and Neeraj, K. (2018) Emission Uniformity Evaluation of Installed Drip Irrigation System. International Journal of Chemical Studies, 6, 1651-1654.

[19] Capra, A. and Scicolone, B. (1998) Water Quality and Distribution Uniformity in Drip/Trickle Irrigation Systems. Journal of Agricultural Engineering Research, 70, 355-365. https://doi.org/10.1006/jaer.1998.0287

[20] Asif, M., Ahmad, M., Mangrio, A.G., Akbar, G. and Wahab, A. (2015) Design, Evaluation and Irrigation Scheduling of Drip Irrigation System on Citrus Orchard. Pakistan Journal of Meteorology, 12, 37-48.

[21] Jatoth, V., Mishra, A.K. and Neelam, P. (2017) Calculation of Uniform Coefficient, Soil Moisture Distribution and Analysis of Level of Biofilms Strategy under Sub Surface Drip Irrigation. International Journal of Current Microbiology and Applied Sciences, 6, 713-726. https://doi.org/10.20546/ijcmas.2017.610.088

[22] USDA-NRCS (2018) Using Soil Textural Triangle. Soil Science Curriculum. University of Nebraska Institute of Agriculture and Natural Resources, CROPWATCH.

[23] Akhtar, M.M., Tang, Z. and Mohamadi, B. (2014) Contamination Potential Assessment of Potable Groundwater in Lahore. Polish Journal of Environmental Studies, 23, 1095-1916.

[24] FAO (2019) Safety and Quality of Water Used in Food Production and Processing. Microbiological Risk Assessment Series Meeting Report. Roma.

[25] Kahlown, M.A., Tahir, M.A., Rashid, H. and Bhatti, K.P. (2006) Water Quality Status. Fourth Technical Report 2004-06, PCRWR, Islamabad, Organization of the United Nations, World Health Organization, Rome.

[26] James, L.G. (1993) Principles of Farm Irrigation Systems Design. Krieger Publishing Company, Malarbar.

[27] Smajstrla, A., Boman, G.B.J., Haman, D.Z., Pitts, D.J. and Zazueta, F.S. (2012) Field Evaluation of Microirrigation Water Application Uniformity. Agricultural and Biological Engineering Department, Florida Cooperative Extension Service, Institute of Food and Agricultural Sciences, University of Florida, Gainesville, 1-10.

[28] Storlie, C. (1995) Treating Drip Irrigation System with Chlorine. Ruthgers Cooperative Extension Services Fact Sheet FS795.

[29] Al-Ghobari, H.M. (2012) A Comparison of Water Application Uniformity for Drip Irrigation System above and below Soil Surface at Various Soil Depths and Scheduling Techniques in Arid Region. Sustainable Irrigation and Drainage, 168, 311-319. https://doi.org/10.2495/SI120271

[30] Isikwue, M.O., Ochedikwu Anthea, E.F. and Onoja, S.B. (2016) Small Farm Gravity Drip Irrigation System for Crop Production. Greener Journal of Science, Engineering and Technological Research, 6, 48-54. https://doi.org/10.15580/GJSETR.2016.2.061416105

[31] Roberto, N. (2005) Fertilization Combined with Irrigation (Fertigation). Extension Service Irrigation and Soil Field Service, 2-5.

[32] Ochedikwu, A.E.F. (2015) Performance Evaluation of Small Farm Gravity Drip Irrigation System for Vegetable Production. Master of Engineering Thesis, The Department of Agricultural and Environmental Engineering, University of Agriculture, Makurdi. 